\title{
A Little History of Darwinian History
}

\author{
Laura Betzig
}

Evolutıon \& Human Behavior Program, University of Michigan, Ann Arbor, Michigan

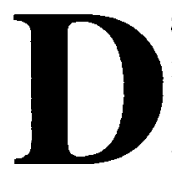
arwinian history? Obviously In the last half century, biology has moved toward history, and history has moved toward biology Sooner or later, they had to come together Darwin seemed to think so He said, at the end of his book on the Origin of Species, "much light will be thrown on mankınd and his history" (1859 573) But it took more than a hundred years

It isn't clear why the walt was so long (but see, e g, Freeman 1983 chapters 1-4, Haraway 1989' chapter 6, and especially Degler 1991). For whatever reason, around the middle of this century, it took a handful of men to bring Darwinian theory back to the study of behavior They asked two basic questions First. What is the most important level of selection? Do individuals, or genes, or groups struggle to exist-and to reproduce? Their answer was that selection is most effective at the individual level (Williams 1966; but see Wilson 1980, Dawkins 1982) Second Then what accounted for altruism? Why did one individual ever go out of its way to help another? One answer was that individuals could reproduce both directly and through their famılies - through kın who shared their genes (Hamilton 1964) Another was, they might help in order to get helped back (Trivers 1971, Axelrod and Hamilton 1981). Answers to those questions started a revolution in the study of anımal behavior (reviews in Daly and Wılson 1983, Trivers 1985, Krebs and Davies 1987, 1991, Alcock 1989, Cockburn 1991) They started a revolution in the study of human behavior, too

That new theory was the first step biology took toward history The second was an empirical one Inspired by the work of Richard Alexander, a biologist, Napoleon Chagnon and William Irons, two anthropologists, published the first tests of Darwinian hypotheses on human behavior in 1979 (Alexander 1974, 1979, Chagnon and Irons 1979) The papers in that book show, or try to show, that alliances in a tribal ax fight, the acquisition of capital in Persia, and female infanticide in high Indian castes, among other

Recelved December 31, 1991, revised June 18, 1992

Address reprınt requests to I aura Betzıg, Evolutıon \& Human Rehavior Program, 100H Rackham BIdg, University of Michigan, Ann Arbor MI 48109 
things, are adaptive-that is, that they help individuals to reproduce Since then, dozens of studies have shown that people in hunting and gathering. herding, horticultural, fishıng, farmıng, and even industrial societıes appear to do all sorts of thıngs adaptively (reviews in Betzig 1988, Cronk 1991, Borgerhoff Mulder 1991) More than a few of these studies have been done in historical societies Mildred Dickemann, the "mother" of Darwinian history, publıshed a trilogy of papers in 1979 and 1981, on societıes as far flung as ancient India and China, medieval Europe, and the Middle East, on topıcs as wide-ranging as religious claustration, footbinding and infibulation, hypergyny and dowry, as aspects of individual reproductive competition They were inspiring papers More than any others. they were responsible for the Darwinian history that followed for the next twelve years, including comparatıve studies (e g , Hartung 1982, Betzıg 1986. Gaulın and Boster 1990), and detailed studies of late medieval Portugal (Boone 1986, 1988), early modern Germany (Voland 1984, 1988), early modern Sweden (e g , Low, Clarke, and Lockridge 1991), and modern North America (Smith, Kish, and Crawford 1987, Betzig and Weber 1992, Hrdy and Judge 1992)

So biology has moved toward history How has history moved toward biology" In at least two ways First, much of history has taken a quantitative turn-especially family history And historians aren't just countıng populations, they're counting individuals and households (e g, Wrigley and Schofield 1981) They're looking at the tens of thousands of epitaphs on the tombs from imperial Rome (e g, Saller and Shaw 1984), at the 15th century Florentıne catasto and earlier censuses of medieval monasteries (e g . Herlihy 1985), and at parish and other records from modern societies (e g , Laslett and Wall 1972) They're asking how social varables, like status and wealth, affect famıly variables, like numbers of mates and children They are, in other words, excitıngly close to doing what behavioral biologists have done with species as diverse as fruit flies and red deer (e g, Clutton-Brock 1988) But they've lacked biological theory That's what four papers in this issue interject Røskaft, Wara, and Viken's Norweglan study, Low and Clarke's Swedısh study. Judge and Hrdy's Calıformı study, and Smuts' U S study all ask within a society, do people respond to their environments adaptively?

The second way history has moved toward biology is by adopting the comparative method Comparison is essential to naturalism-across species (e g , Harvey and Pagel 1991) and across societres (e g , Spencer 1876-1896. Murdock 1949, Goody 1976a) That includes historical societies More than anybody, Jack Goody has opened the eyes of historians to the use of comparıson in makıng generalizations He's looked at varıation in "strategies of heirship," among other things, across ancient (Goody 1990), medieval (Goody 1983), and more modern societies (Goody 1976b) Though historians have sometimes been critical of his conclusions, they're often enthusiastic about his comparisons (Kertzer and Saller 1991 is just one recent example) Agaın, what we add here is biological theory Four other papers in this 
volume-mine on Roman polygyny and monogamy, Hager's on medieval nunneries, and Hrdy's on delegated motherıng-ask do people respond adaptively to their environments across societies as well?

Since history and biology seem to have converged from both directions, in the best of all worlds, this issue should have been written by both biologists and historians Sad to say, only one of the contributors is a historian-Bob Smuts, who wrote Women and Work in America in 1959, retired from Columbia University years ago We're honored to have him The other contributors are all anthropologists (Betzıg, Hrdy, and Judge) or biologists (Clarke, Hager, Low, Røskaft, Wara, and Viken) But, I'm pleased to say, we've had enormous and extremely useful input from some of the best historians We are sincerely grateful to Keith Bradley, John Crook, Suzanne Dixon, Jane Gardner, Barbara Hanawalt, Sheıla Johannson, Ken Lockridge, Sarah Pomeroy, Beryl Rawson, Richard Saller, Eleanor Searle, Jan Sundeın, Susan Treggırı, Marıs Vinovskıs, and E A Wrigley for generously and often painstakıngly commentıng on these papers We're grateful too to the many good anthropologists, biologists, and psychologists who reviewed and improved them And we're especially grateful to Michael McGuire for giving us this opportunity to bring historians and biologists together at last

Overall, I thınk these papers suggest-lıke so much done in the last fourteen years-that people within and across societies often do respond to their environments adaptıvely They don't always there are some puzzles But, to me, sex and marriage in ancient Rome, nepotısm in medieval nunneries, wet nursing and other kınds of "delegated motherıng" across European history, famıly plannıng in early modern Sweden and Norway, inheritance in Sacramento, and men's tastes for thın $\Lambda$ merican women, are all in some ways better understood as individuals' means to reproductive ends

Let the work speak for itself.

I'd like to thank the great medieval historian, David Herlihy, whom I never met and never corresponded with, for writıng a paper called "Bılogy and History Suggestions for a Dialogue," just before he died last year I thank Kevin MacDonald for sending the paper

\section{REFERENCES}

Alcock, J Animal Behavior An Evolutionary Approach, 4th edition Sunderland MA Sinauer, 1989

Alexander, R The evolution of social behavior Annual Review of Ecology and Systematic 5 325-383, 1974

- Darwinısm and Human Affairs Seattle University of Washıngton Press, 1979

Axelrod, R and Hamiton W The evolution of cooperation Sclence 211 1390-1396, 1981

Betzig, L Despotısm and Differential Reproduction A Darwinan View of History Hawthorne NY Aldine-de Gruyter, 1986

Matıng and parentıng in Darwinian perspectıve In Human Reproductue Behavour A 
Daruınian Perspective, Laura Betzig, Monıque Borgerhoff Mulder, and Paul Turke (Eds) Cambridge Cambridge Unıversıty Press, 1988

-_- and Weher, S Polygyny in American politics Politics and the I, fe So tences 16, 1992

Boone, J Parental investment and elite family structure in preindustrial states A case study of late medieval-early modern Portuguese genealogies Americ an Anthropologist 88 859-878, 1986

_- Parental investment, social subordination, and population processes among the 15 th and 16th century Portuguese nobility In Human Reproductue Behavour A Darninan Perspective. Laura Betaig. Monique Borgerhoff Mulder. and Paul Turke (Eds) Cambridge Cambridge University Press, 1988

Borgerhoff Mulder, M Human behavioural ecology In Behatioural Ecology An Eiolitionary Approac $h$, Third edition, John Krebs and Nick Davies (Eds) Sunderland MA Sinauer, 1991

Chagnon, N and Irons W (Eds ) Evolutionary Btology and Human Soctal Behator An Anthropologi al Perspectuve, North Scituate MA Duxbury Press 1979

Clutton-Brock, T (Ed) Reproductwe Success Chicago University of Chicago Press 1988

Cockburn, A An Introduction to Evolutionary Ecology Oxtord, Blackwell. 1991

Cronk, L Human behavioral ecology Annual Revew's of Anthropology $20 \quad 25-531991$

Daly, $M$ and Wilson, M Sex, Evolution, and Behavior, Second edition Boston Willard Grant. 1983

Darwin, C On the Origin of Specles London John Murray, 1859 (Quote from reprint by Modern Library, New York, n d)

Dawkıns, R The Extended Phenotype The Gene as the Unt of Selection Oxford W $\mathrm{H}$ Freeman, 1982

Degler, C In Search of Human Nature The Decline and Revwal of Daw whism in Americ an Social Thought Oxford Oxford University Press, 1991

Dickemann, M Female infantıcıde, reproductıve strategies, and socidl stratıfication a prelıminary model In, Chagnon and Irons, op $c t t, 1979 d$

- The ecology of matıng systems in hypergynous dowry societies Social Science Information 18 163-195, 1979b

Paternal confidence and dowry competition A biocultural analysis of purdah In Nattual Selectuon and Social Behavor Rec ent Research and New'Theon Richard Alexander and Donald Tinkle (Eds) New York Chiron Press, 1981

Freeman, D Margaret Mead and Samoa The Making and Unmaking of an Anthropological Myth Cambridge Harvard University Press, 1983

Gaulın, S and Boster J Dowry as female competıtion Amencan Anthropologist 92 994-1005. 1990

Goody, J Production and Reproduction Cambridge Cambridge University Press, 1976a

Inheritance, property and women some comparative considerdtons In Famil and Inheritance Rural Soctety in Western Europe 1200-1800, Jack Goody Jodn Thirsk and E P Thompson (Eds) Cambridge Cambridge University Press, $1976 \mathrm{~b}$

- The Development of the Family and Marrage in Europe Cambudge Cambridge University Press, 1983

- The Ortental, the Anctent, and the Prmmitse Cambridge Cambradge Univerity Press 1990

Hamition, W The genetical evolution of social behavior Jom nal of Theoretical Biology 7 52,1964

Haraway, D Primate Vistons Gender Race, and Nature in the World of Modern Sctence New York Routledge, 1989

Harvey, $\mathrm{P}$ and Pagel, M D The Comparatue Method in Elolutonan Bolog Oxtord Oxtord University Press, 1991

Hartung, J Polygyny and the inheritance of wealth Current Anthopologv 23 1-12, 1982

Herlihy, D Medieval Household, Cambridge Harvard University Press, 1985

Hrdy Blaffer $S$ and Judge, D Parental investment after death The puzzle of primogeniture In preparation, 1992

Kertzer. J and Saller, R The Family in Italy From Antiquts to the Present New Haven Yale University Press, 1991

Krebs, J and Davies, N An Introductuon to Behavioural Ecology, second edition Oxford Blackwell, 1987 
- Behavioural Ecology An Evolutionary Approach, third edition Sunderland MA Sinauer, 1991

Laslett, P and Wall, R (Eds) Household and Family in Past Time Cambridge Cambridge Unıversity Press, 1972

Low, B , Clarke, A , and Lockridge, K Family Patterns in Nineteenth-Century Sweden Vartatıon in Time and Space Umea Demographic Database Monograph No 6, 1991

Murdock, G P Social Structure New York The Free Press, 1949

Saller, $\mathrm{R}$ and Shaw, B Tombstones and Roman family relations in the Principate Civilians, soldiers and slaves Journal of Roman Studies 74 124-156, 1984

Smith, M , Kısh, B , and Crawford, C Inheritance of wealth as human kin investment Ethology and Soctobiology $8 \quad 171-182,1987$

Smuts, R Women and Work in America New York Columbia Unıversity Press, 1959

Spencer, H Principles of Soctology New York Appleton, 1876-1896

Trivers, $\mathrm{R}$ The evolution of reciprocal altruism Quarterly Review of Biologv 46 35-57. 1971 Social Evolution Menlo Park Benjamın/Cummıngs, 1985

Voland, E Human sex-ratio manıpulation Historical data from a German partsh Journal of Human Evolution 13 99-107, 1984

Differential infant and child mortality in evolutionary perspective Data from late 17 th to 19 th century Ostfriesland (Germany) In Human Reproductive Behaviour A Darn'man Perspective, Laura Betzıg, Monıque Borgerhoff Mulder, and Paul Turke (Eds) Cambridge Cambridge University Press, 1988

Willams, G Adaptation and Natural Selection A Critique of Some Current Evoluttonary Thought Princeton Princeton University Press, 1966

Wilson, D S The Natural Selection of Populations and Communttes Menlo Park Benjamın/Cummıngs, 1980

Wrigley, E A and Schofield, R The Population History of England, 154I-1871 Cambridge Harvard University Press, 1981 